\title{
Anion Conductance Behavior of the Glutamate Uptake Carrier in Salamander Retinal Glial Cells
}

\author{
Brian Billups, David Rossi, and David Attwell \\ Department of Physiology, University College London, London WC1E 6BT, United Kingdom
}

Glutamate uptake is driven by the cotransport of $\mathrm{Na}^{+}$ions, the countertransport of $\mathrm{K}^{+}$ions, and either the countertransport of $\mathrm{OH}^{-}$or the cotransport of $\mathrm{H}^{+}$ions. In addition, activating glutamate uptake carriers has been shown to lead to activation of an anion conductance present in the carrier structure. Here we characterize the ion selectivity and gating of this anion conductance. The conductance is small with $\mathrm{Cl}^{-}$as the permeant anion, but it is large with $\mathrm{NO}_{3}^{-}$or $\mathrm{ClO}_{4}^{-}$present, undermining the earlier use of $\mathrm{NO}_{3}^{-}$and $\mathrm{ClO}_{4}^{-}$to suggest that $\mathrm{OH}^{-}$ countertransport rather than $\mathrm{H}^{+}$cotransport helps drive uptake. Activation of the anion conductance can be evoked by extra- or intracellular glutamate and can occur even when glutamate transport is inhibited. By running the carrier backward and detecting glutamate release with AMPA receptors in neurons placed near the glial cells, we show that anion flux is not coupled thermodynamically to glutamate movement, but $\mathrm{OH}^{-} / \mathrm{H}^{+}$transport is. The possibility that cell excitability is modulated by the anion conductance associated with glutamate uptake suggests a target for therapeutic drugs to reduce glutamate release in conditions like epilepsy.

Key words: glutamate; transporter; anion conductance; uptake; $\mathrm{pH}$; glial cell
The extent to which glutamate uptake can lower the extracellular glutamate concentration in the CNS is determined by the ionic stoichiometry of the uptake process (Attwell et al., 1993). Entry of each glutamate ion into the cell is thought to be accompanied by the cotransport of two $\mathrm{Na}^{+}$ions (Baetge et al., 1979; Stallcup et al., 1979; Erecinska et al., 1983) and the countertransport of one $\mathrm{K}^{+}$ion (Kanner and Sharon, 1978; Barbour et al., 1988; Amato et al., 1994). In addition, glutamate uptake carriers generate $\mathrm{pH}$ changes, acid inside the cells and alkaline outside (Erecinska et al., 1983; Bouvier et al., 1992). Bouvier and colleagues (1992) suggested that, for the glutamate transporter in salamander retinal glia, power is obtained from the transmembrane $\mathrm{pH}$ gradient by the transport of an $\mathrm{OH}^{-}$ion out of the cell rather than the (thermodynamically equivalent) transport of an $\mathrm{H}^{+}$ion into the cell. This was based on the observation that, when certain anions $\left(\mathrm{NO}_{3}^{-}, \mathrm{ClO}_{4}^{-}\right.$, and $\left.\mathrm{SCN}^{-}\right)$were inside the cell, the inward current evoked by external glutamate was larger, but the $\mathrm{pH}$ change generated was unaffected or reduced, and that anion-sensitive electrodes detected the efflux of $\mathrm{ClO}_{4}^{-}$from cells containing $\mathrm{ClO}_{4}^{-}$. It was suggested that $\mathrm{NO}_{3}^{-}, \mathrm{ClO}_{4}^{-}$, and $\mathrm{SCN}^{-}$competed for transport on a carrier site that normally transports $\mathrm{OH}^{-}$.

The cloned mammalian glutamate transporters (Fairman et al., 1995; Wadiche et al., 1995) and the transporters in salamander photoreceptors and glia and in fish bipolar cells (Sarantis et al., 1988; Eliasof and Werblin, 1993; Grant and Dowling, 1995; Picaud et al., 1995; Eliasof and Jahr, 1996) activate an anion conductance when they bind external glutamate and $\mathrm{Na}^{+}$. However, it is unclear how the binding of substrate to the carrier gates the anion conductance. Can the anion conductance component of the transporter be activated by intracellular glutamate during

\footnotetext{
Received May 23, 1996; revised Aug. 13, 1996; accepted Aug. 16, 1996.

This work was supported by the Wellcome Trust, Medical Research Council, and European Community (contract CT95-0571). We thank Alasdair Gibb, Akiko Momiyama, and Angus Silver for comments on this manuscript.

Correspondence should be addressed to Dr. David Attwell at the above address.

Copyright (C) 1996 Society for Neuroscience $0270-6474 / 96 / 166722-10 \$ 05.00 / 0$
}

reversed uptake as well as by external glutamate during forward uptake? Is it even necessary for glutamate transport to occur for the anion conductance to open, or is glutamate binding sufficient? The presence of an anion conductance in the transporter structure also raises the possibility that the effects of $\mathrm{NO}_{3}^{-}, \mathrm{ClO}_{4}^{-}$, and $\mathrm{SCN}^{-}$on the salamander glial carrier were exerted not through the postulated $\mathrm{OH}^{-}$-binding site but through the anion conductance component of the transporter molecule (Eliasof and Jahr, 1996). It further brings into question whether the observed $\mathrm{pH}$ changes are a result of substrate transport or are attributable to $\mathrm{pH}$-changing anions passing through the anion conductance.

Here we investigate the gating of the anion conductance in the salamander glial glutamate transporter. We show that the anion conductance can be activated by glutamate binding to either side of the membrane and can occur independently of whether net glutamate transport occurs, suggesting that it is activated by a conformation change, which is allowed when the carrier is in a particular state of its uptake cycle. Transport of $\mathrm{OH}^{-}\left(\right.$or $\left.\mathrm{H}^{+}\right)$is shown to be coupled to glutamate transport and shown not to occur through the anion conductance.

\section{MATERIALS AND METHODS}

All experiments were done at room temperature, $25^{\circ} \mathrm{C}$.

Salamander retinal glial cells. Glial (Müller) cells were isolated from tiger salamander retinae by using papain, as described previously (Barbour et al., 1991), and whole-cell-clamped with pipettes of series resistance (in whole-cell mode) $\sim 3 \mathrm{M} \Omega$, which leads to negligible series resistance voltage errors $(<2 \mathrm{mV})$. Large pipettes are essential for dialyzing the cell adequately in experiments removing intracellular potassium from the cell (Szatkowski et al., 1991). When currents were compared in different cells, they were normalized by cell capacitance to compensate for variations in cell size (Barbour et al., 1991).

Solutions. Unless otherwise stated, the extracellular solution contained (in mM): $\mathrm{NaCl} 105, \mathrm{KCl} 2.5, \mathrm{CaCl}_{2} 3, \mathrm{MgCl}_{2} 0.5$, glucose 15, HEPES 5, and $\mathrm{BaCl}_{2} 6$ (to block the inward rectifier potassium channels of the cells), $\mathrm{pH}$-adjusted to 7.3 with $\mathrm{NaOH}$. A $1 \mathrm{M} \mathrm{NaCl}$ agar bridge was used as the bath electrode to reduce (to $<0.4 \mathrm{mV}$ ) junction potential changes when changing the anion in the external solution. Unless otherwise stated, the standard pipette solution for uptake experiments contained (in 
mM): $\mathrm{KCl} 95, \mathrm{NaCl} 5, \mathrm{HEPES} 5, \mathrm{MgCl}_{2} 7, \mathrm{Na}_{2} \mathrm{ATP} 5, \mathrm{CaCl}_{2} 1$, and $\mathrm{K}_{2}$ EGTA 5, pH-adjusted to 7.0 with $14 \mathrm{mM} \mathrm{KOH}$. The pipette solution for studying the effect of $\left[\mathrm{K}^{+}\right]_{\mathrm{i}}$ on the anion conductance (see Fig. $3 C, D$ ) was as above [but $\mathrm{pH}$-adjusted with $N$-methyl-D-glucamine (NMDG) and with $(\mathrm{NMDG})_{2}$ EGTA instead of $\mathrm{K}_{2}$ EGTA] or with $\mathrm{KCl}$ replaced by choline- $\mathrm{Cl}$; for these experiments, the external solution was as above, but with $0.1 \mathrm{~mm}$ ouabain added, $\mathrm{KCl}$ omitted (Barbour et al., 1988), and with $105 \mathrm{~mm} \mathrm{NaCl}$ replaced by $25 \mathrm{~mm} \mathrm{NaCl}$ and $30 \mathrm{~mm}$ choline-Cl plus $50 \mathrm{~mm}$ of either $\mathrm{NaCl}$ or $\mathrm{NaNO}_{3}$ (pH was adjusted with NMDG). The pipette solution for studying uptake with strong $\mathrm{pH}$ buffering contained (in $\mathrm{mM}$ ): $\mathrm{KCl} 50$, HEPES 71, NMDG 26, $\mathrm{NaCl} 5$, (NMDG) ${ }_{2}$ EGTA 5, $\mathrm{CaCl}_{2} 1$, $\mathrm{MgCl}_{2}$ 7, and $\mathrm{Na}_{2} \mathrm{ATP} 5$, pH 7.0; that for reversed uptake usually contained (in mM): Na-glutamate 10, choline-Cl 40, HEPES 71, NMDG 25, (NMDG) $)_{2}$ EGTA 5, $\mathrm{CaCl}_{2} 1, \mathrm{MgCl}_{2} 7$, and $\mathrm{Na}_{2}$ ATP 5, pH set to 7.0 with NMDG. When we studied the effects of internal anions on the anion conductance activated during reversed uptake (see Fig. $4 B$ ), the pipette solution contained (in $\mathrm{mM}$ ): Na-glu 10, choline-Cl $85\left(\right.$ for $\mathrm{Cl}^{-}$) or 35 $\left(\mathrm{ClO}_{4}^{-}\right)$, choline- $\mathrm{ClO}_{4}^{-} 0\left(\mathrm{Cl}^{-}\right)$or $50\left(\mathrm{ClO}_{4}^{-}\right)$, NaCl 5, HEPES 5, (NMDG) $)_{2}$ EGTA 5, $\mathrm{Na}_{2} \mathrm{ATP} 5, \mathrm{CaCl}_{2} 1$, and $\mathrm{MgCl}_{2} 7$, pH set to 7.0 with NMDG. When we studied activation of the anion conductance with net glutamate transport inhibited (see Fig. $5 A$ ), the pipette solution contained (in mM): Na-glu 100, MgATP 5, HEPES 5, $\mathrm{CaCl}_{2} 1,(\mathrm{NMDG})_{2}$ EGTA 5, and $\mathrm{MgCl}_{2} 2$, pH set to 7.0 with NMDG; the external solution contained (in $\mathrm{mM}$ ): $\mathrm{NaCl} 100$, choline- $\mathrm{Cl} 10, \mathrm{MgCl}_{2} 0.5, \mathrm{CaCl}_{2} 3, \mathrm{HEPES}$ 5 , glucose $15, \mathrm{BaCl}_{2} 6$, and ouabain 0.1 . When we studied the effect of intracellular $\left[\mathrm{Na}^{+}\right]$and $\left[\mathrm{glu}^{-}\right]$on the anion conductance with net glutamate transport inhibited (see Fig. $5 B$ ), the pipette solution contained blockers of the Krebs' cycle, glutamate transaminase, and glutamine synthetase to allow better control of $\left[\mathrm{glu}^{-}\right]_{\mathrm{i}}$ and comprised (in $\mathrm{mM}$ ): $\mathrm{NaCl}$ 0 or 10 , NMDG-glutamate 0 or 10 , choline-Cl 100 (for $0 \mathrm{Na}^{+} / 0 \mathrm{glu}^{-}$), 90 (for $10 \mathrm{Na}^{+} / 0 \mathrm{glu}^{-}$or $0 \mathrm{Na}^{+} / 10 \mathrm{glu}^{-}$), or 80 (for $10 \mathrm{Na}^{+} / 10 \mathrm{glu}^{-}$), $\mathrm{CaCl}_{2}$ 1, (NMDG) $)_{2}$ EGTA 5, MgATP 5, HEPES 5, $\mathrm{MgCl}_{2} 2$, malonic acid 0.2, amino-oxyacetic acid 5, and L-methionine sulfoximine 2, $\mathrm{pH}$ set to 7.0 with NMDG; the external solution was as just described, but with choline- $\mathrm{Cl}$ replaced by $\mathrm{NaCl}$. Electrode junction potentials were compensated (Fenwick et al., 1982).

$I-V$ plots. These were derived from the steady-state current measured at the end of $150 \mathrm{msec}$ voltage steps from a holding potential of $-50 \mathrm{mV}$. Glutamate-evoked currents were obtained from the $I-V$ data in glutamate by subtracting the average of control $I-V$ data obtained before and after glutamate.

Sensing glutamate release with isolated Purkinje cells. This was performed as described by Billups and Attwell (1996). Cerebellar Purkinje cells were isolated from $200-\mu$ m-thick slices of cerebellum from 12 -d-old rats by incubation in papain, as for salamander glia (Barbour et al., 1991), except that the tonicity of the incubation and washing solution was increased to that for rat cells by raising the $\mathrm{NaCl}$ concentration by $20 \mathrm{~mm}$. After isolation and plating of the cells into the recording chamber, the solution outside the cells was altered to standard solution of the tonicity for salamander cells: this did not seem to damage the cells. Purkinje cells were recognized by their large cell bodies and stumps of dendrites and axon. They were whole-cell-clamped with a pipette solution containing (in mM): $\mathrm{CsCl} 110, \mathrm{HEPES} 10, \mathrm{MgCl}_{2} 2, \mathrm{CaCl}_{2}$ 0.5, (NMDG) ${ }_{2}$ EGTA 5, and $\mathrm{Na}_{2}$ ATP 5, pH set to 7.0 with NMDG. Desensitization of Purkinje cell non-NMDA receptors was reduced with $1 \mathrm{~mm}$ trichlormethiazide, and the Purkinje cell then generated a non-NMDA current related to the glutamate concentration by a Hill equation with an $\mathrm{EC}_{50}$ of $23 \mu \mathrm{M}$ and a Hill coefficient of 1.2 (Billups and Attwell, 1996).

Measurement of intracellular $\mathrm{pH}$. This was done as described previously with the pH-sensitive fluorescent dye 2',7'-bis(carboxyethyl)carboxyfluorescein (BCECF; $100 \mu \mathrm{M})$ loaded into the cell in the standard whole-cell pipette solution but buffered with only $0.5 \mathrm{~mm}$ HEPES (Bouvier et al., 1992). Calibration of the $\mathrm{pH}$ was obtained from the response to a weak acid and two concentrations of a weak base (Bouvier et al., 1992).

\section{RESULTS}

\section{Glutamate uptake into salamander retinal glia activates an anion conductance}

Earlier experiments (Brew and Attwell, 1987) found that the glutamate-evoked current in salamander retinal glia is inward and smaller at positive potentials (see Fig. $2 B, D$; data for $0 \mathrm{~mm}$ $\left[\mathrm{NO}_{3}^{-}\right]_{\mathrm{o}}$ and $\left[\mathrm{ClO}_{4}^{-}\right]_{\mathrm{o}}$ ), as expected from activation of a carrier
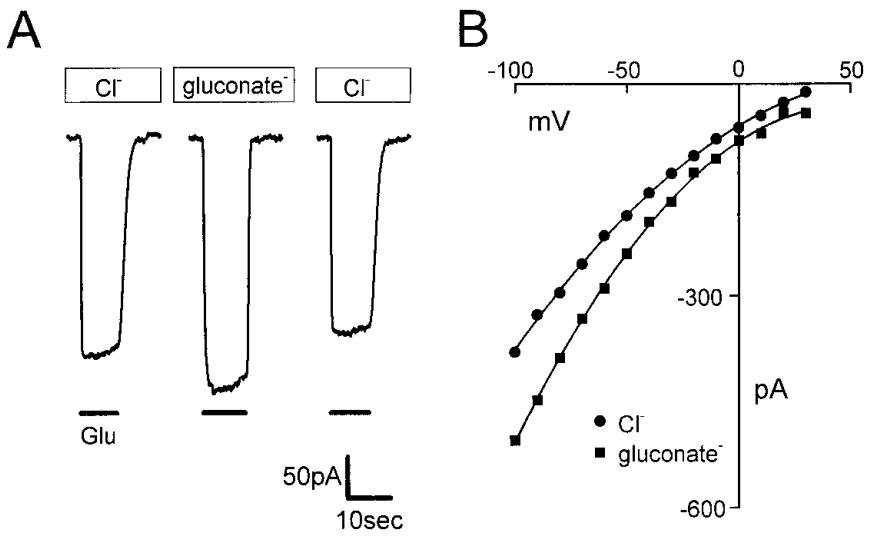

Figure 1. Chloride dependence of the glutamate-evoked current in salamander retinal glia. $A$, Lowering external $\left[\mathrm{Cl}^{-}\right]$from 126.5 to $19 \mathrm{~mm}$ (replaced with gluconate ${ }^{-}$) increased the current evoked by $200 \mu \mathrm{M}$ glutamate (Glu, black bar) at $-60 \mathrm{mV}$. B, Voltage dependence of the glutamate-evoked current in the presence and absence of external $\mathrm{Cl}^{-}$. Data typical of nine cells; pipette and external solution as discussed in Materials and Methods.

that transports two $\mathrm{Na}^{+}$ions into the cell with each glu ${ }^{-}$anion while countertransporting a $\mathrm{K}^{+}$and an $\mathrm{OH}^{-}$ion (Bouvier et al., 1992). If, as has been shown for the cloned mammalian glutamate transporters, activation of the retinal glial carrier also activates an anion conductance, then altering the extracellular chloride concentration should influence the glutamate-evoked current. When external $\mathrm{Cl}^{-}$was lowered from 126.5 to $19 \mathrm{~mm}$, the inward current evoked by $200 \mu \mathrm{M}$ glutamate was increased, consistent with an increase in $\mathrm{Cl}^{-}$efflux through an anion conductance (Fig. 1A,B). In four cells at $-100 \mathrm{mV}$, lowering $\left[\mathrm{Cl}^{-}\right]$increased the current by $15 \pm 6 \%$ SEM. Interestingly, although one might expect the current increase produced by chloride removal to be larger at positive potentials (where the driving force for $\mathrm{Cl}^{-}$influx would be greatest), a larger change was seen at negative voltages (Fig. $1 B$; in 4 cells the current change at $0 \mathrm{mV}$ was $34 \pm 13 \%$ of that at $-100 \mathrm{mV}$ ). This might be attributable to more activation of the anion conductance occurring at more negative potentials when the carrier is cycling more often.

Consistent with the effect of removing external $\mathrm{Cl}^{-}$, we found that the glutamate-evoked current was smaller in cells clamped with a pipette solution with reduced $\left[\mathrm{Cl}^{-}\right]$. In four and six cells clamped with a pipette solution containing 116 or $21 \mathrm{mM} \mathrm{Cl}^{-}$, respectively, the current evoked by $200 \mu \mathrm{M}$ glutamate at $-100 \mathrm{mV}$ (normalized by cell capacitance) was $2.7 \pm 0.2$ and $2.0 \pm 0.2$ $\mathrm{pA} / \mathrm{pF}$. In the six cells studied with lowered $\left[\mathrm{Cl}^{-}\right]_{\mathrm{i}}$, lowering external $\left[\mathrm{Cl}^{-}\right]$increased the glutamate-evoked inward current, as in Figure 1.

\section{The anion conductance is more permeable to $\mathrm{NO}_{3}^{-}$and $\mathrm{ClO}_{4}^{-}$than to $\mathrm{Cl}^{-}$}

Intracellular $\mathrm{NO}_{3}^{-}, \mathrm{SCN}^{-}$, and $\mathrm{ClO}_{4}^{-}$(replacing $\mathrm{Cl}^{-}$) increase the inward current generated by the uptake carrier when glutamate is applied extracellularly (Bouvier et al., 1992). With $\mathrm{ClO}_{4}^{-}$or $\mathrm{NO}_{3}^{-}$ present extracellularly but not intracellularly, the glutamateevoked current was outward at depolarized potentials (Fig. $2 A, B, D)$. An outward current is not expected from external glutamate activating a carrier that transports two $\mathrm{Na}^{+}$ions in with each $\mathrm{glu}^{-}$and transports a $\mathrm{K}^{+}$and an $\mathrm{OH}^{-}$out of the cell, as proposed earlier (Bouvier et al., 1992), but it could be explained by $\mathrm{ClO}_{4}^{-}$entering the cell through an anion conductance linked to the carrier (Eliasof and Jahr, 1996). 

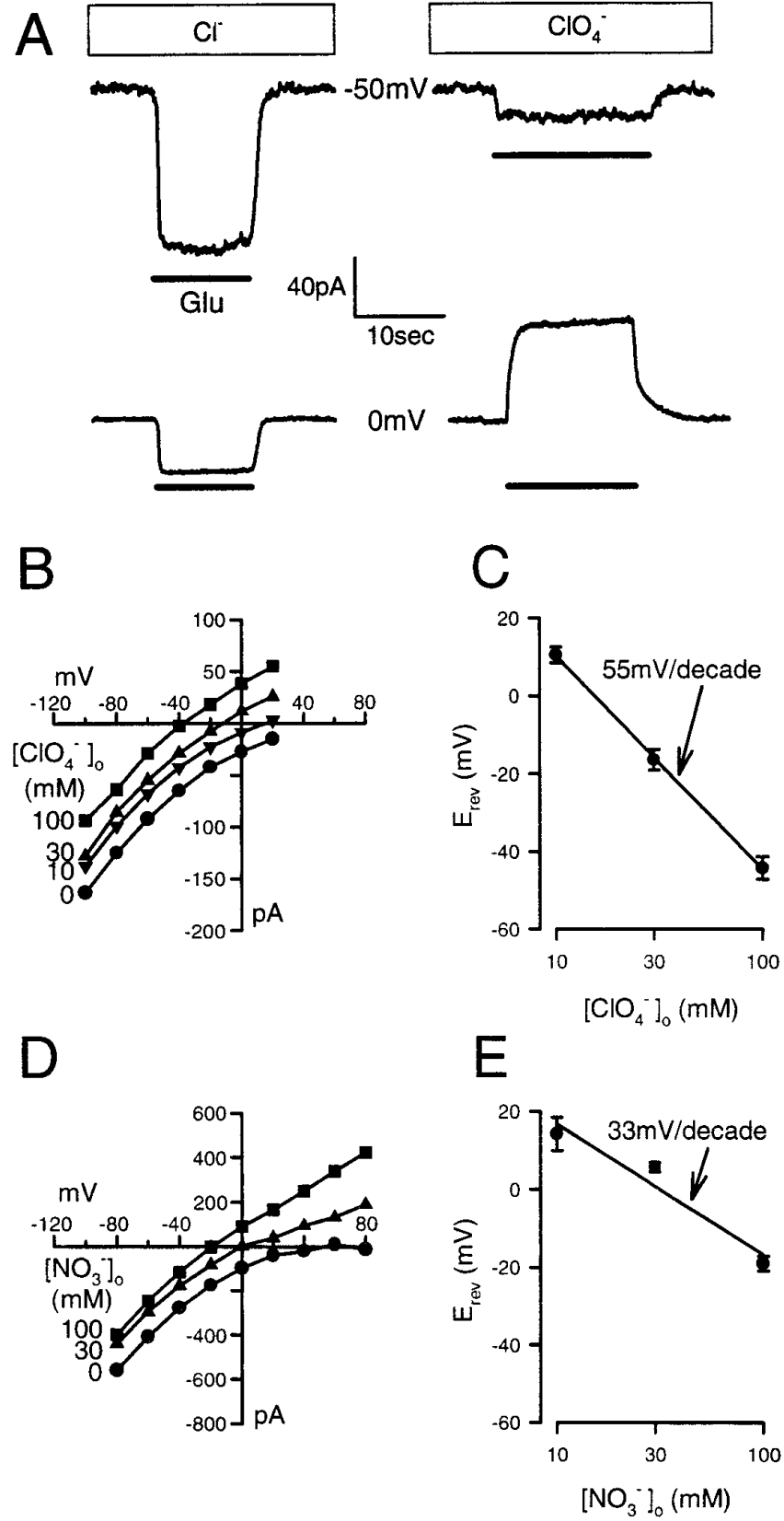

Figure 2. With $\mathrm{ClO}_{4}^{-}$or $\mathrm{NO}_{3}^{-}$present outside the cell, glutamate produces an outward current at positive potentials. $A$, Specimen currents evoked by $200 \mu \mathrm{M}$ glutamate $(G l u)$ at -50 and $0 \mathrm{mV}$ with $\mathrm{Cl}^{-}$as the main external anion (left; external solution as in Materials and Methods) or with $100 \mathrm{mM} \mathrm{Cl}^{-}$replaced by $\mathrm{ClO}_{4}^{-}$(right). $B, I-V$ data for the glutamateevoked current show that, with $\mathrm{Cl}^{-}$outside, the current is inward at all potentials but decreases toward zero at positive potentials, whereas with $\mathrm{ClO}_{4}^{-}$outside, the current reverses at depolarized potentials. In four cells the mean \pm SEM outward current at $+20 \mathrm{mV}$ in $100 \mathrm{mM} \mathrm{ClO}_{4}^{-}$was $60 \pm$ 9 pA. $C$, Dependence on $\left[\mathrm{ClO}_{4}^{-}\right]_{\mathrm{o}}(\log$ scale $)$ of the reversal potential for currents studied as in $B$ (mean \pm SEM; $n=4$ cells for $10 \mathrm{mM}, 5$ for $30 \mathrm{~mm}$, 6 for $100 \mathrm{mM}$ ). $D$, Experiments are as in $B$ but with $\mathrm{NO}_{3}^{-}$replacing external $\mathrm{Cl}^{-}$. E, Dependence on $\left[\mathrm{NO}_{3}^{-}\right]_{\mathrm{o}}$ of the reversal potential for currents studied as in $D$ ( $n=5$ cells for $10 \mathrm{~mm}, 7$ for $30 \mathrm{~mm}, 17$ for $100 \mathrm{~mm})$.

The glutamate-evoked currents recorded with different external $\left[\mathrm{ClO}_{4}^{-}\right]$showed $\mathrm{I}-\mathrm{V}$ relations characteristic of an anion conductance with a relatively high permeability to $\mathrm{ClO}_{4}^{-}$(Fig. $2 \mathrm{~B}$ ). Best-fitting a straight line to the dependence on $\log \left(\left[\mathrm{ClO}_{4}^{-}\right]_{\mathrm{o}}\right)$ of the reversal potential of the $I-V$ relations gave an average shift of $55 \mathrm{mV}$ per 10 -fold change of $\left[\mathrm{ClO}_{4}^{-}\right]_{\mathrm{o}}$ (Fig. $2 \mathrm{C}$ ). Similar results were obtained with $\mathrm{NO}_{3}^{-}$as the anion replacing $\mathrm{Cl}^{-}$, except that less outward current was generated at positive potentials (relative to the inward current at negative potentials) with $\mathrm{NO}_{3}^{-}$present outside (Fig. 2D,E); on average, the reversal potential shifted by $33 \mathrm{mV}$ for a 10 -fold change of $\left[\mathrm{NO}_{3}^{-}\right]_{0}$. To test whether the anion conductance is permeable to $\mathrm{HCO}_{3}^{-}$, we changed the external solution to one buffered to $\mathrm{pH} 7.3$ with $5 \% \mathrm{CO}_{2} / 26 \mathrm{~mm} \mathrm{HCO}_{3}^{-}$ (using a highly buffered pipette solution to minimize changes of intracellular $\mathrm{pH}$; see Materials and Methods). This made the glutamate-evoked current less inward at negative potentials (by $24 \pm 8 \%$ SEM at $-40 \mathrm{mV}$ in 4 cells), consistent with some $\mathrm{HCO}_{3}^{-}$ entering through the anion conductance, but it did not result in the current becoming net outward at positive potentials $(+50 \mathrm{mV})$ unlike with $30 \mathrm{~mm} \mathrm{NO}_{3}^{-}$or $\mathrm{ClO}_{4}^{-}$.

We interpret these results, similar to Wadiche et al. (1995), in terms of the glutamate-evoked current having two components: a current generated by the glutamate-transporting part of the molecule, which is always inward and decreases at more positive potentials, and a current generated by an anion conductance, which is highly permeable to $\mathrm{ClO}_{4}^{-}$(giving a reversal potential that depends in an almost Nernstian manner on $\left.\left[\mathrm{ClO}_{4}^{-}\right]\right)$, less permeable to $\mathrm{NO}_{3}^{-}$(producing a less-than-Nernstian dependence of reversal potential on $\left[\mathrm{NO}_{3}^{-}\right]$), and even less permeable to $\mathrm{Cl}^{-}$ and $\mathrm{HCO}_{3}^{-}$. With $\mathrm{Cl}^{-}$as the main intra- and extracellular anion, the glutamate-evoked current at positive potentials is dominated by the transporter part of the molecule (as judged by the lack of a net outward current seen at positive potentials). With external $\mathrm{ClO}_{4}^{-}$or $\mathrm{NO}_{3}^{-}$present, an outward current through the anion conductance is seen at positive potentials. Because glutamate transport is greatly reduced at positive potentials, this suggests that, for the anion conductance to be activated, it may not be necessary for net glutamate transport to occur. Experiments described below will confirm this and show that ion movements through the anion conductance are not coupled to the flux of glutamate.

\section{Activation of the anion conductance by external glutamate is dependent on external $\mathrm{Na}^{+}$and internal $\mathbf{K}^{+}$}

Replacing external sodium with choline abolished the outward current evoked by glutamate with $\mathrm{NO}_{3}^{-}$or $\mathrm{ClO}_{4}^{-}$present outside the cell (Fig. 3A,B) (see also Eliasof and Jahr, 1996) as well as the inward current at negative potentials that may (with $\mathrm{Cl}^{-}$as the main intracellular anion) be generated primarily by glutamate transport. Thus, activation of the anion conductance by external glutamate, like activation of the uptake process, requires external sodium.

Removing intracellular potassium greatly reduces the inward glutamate-evoked current at negative potentials (Barbour et al., 1988, 1991) and abolishes glutamate uptake (Kanner and Sharon, 1978). It also reduces the outward current seen at positive potentials with $\mathrm{NO}_{3}^{-}$present outside the cell (Fig. 3C,D). With $\mathrm{K}^{+}$in the whole-cell pipette, at $+40 \mathrm{mV}$ no glutamate-evoked current is produced with $\mathrm{Cl}^{-}$as the external anion, because transport of glutamate with a net positive charge into the cell is inhibited. With $50 \mathrm{~mm} \mathrm{NO}_{3}^{-}$outside the cell, however, an outward current of $\sim 0.43 \mathrm{pA} / \mathrm{pF}$ of cell capacitance is seen because of $\mathrm{NO}_{3}^{-}$influx through the anion conductance (Fig. $3 C$ ). When the same experiment was done without $\mathrm{K}^{+}$in the pipette (Fig. $3 D$ ), no glutamateevoked current was seen at any potential with $\mathrm{Cl}^{-}$as the external 

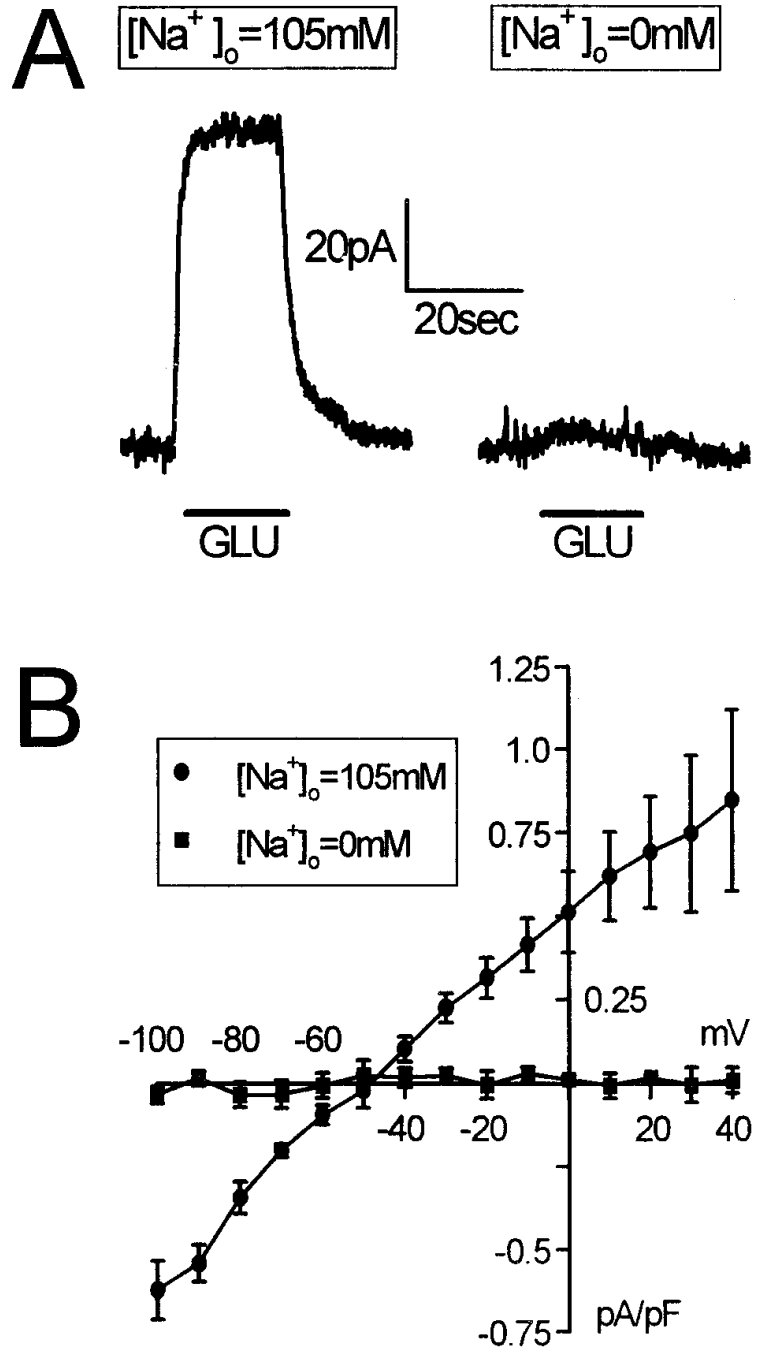

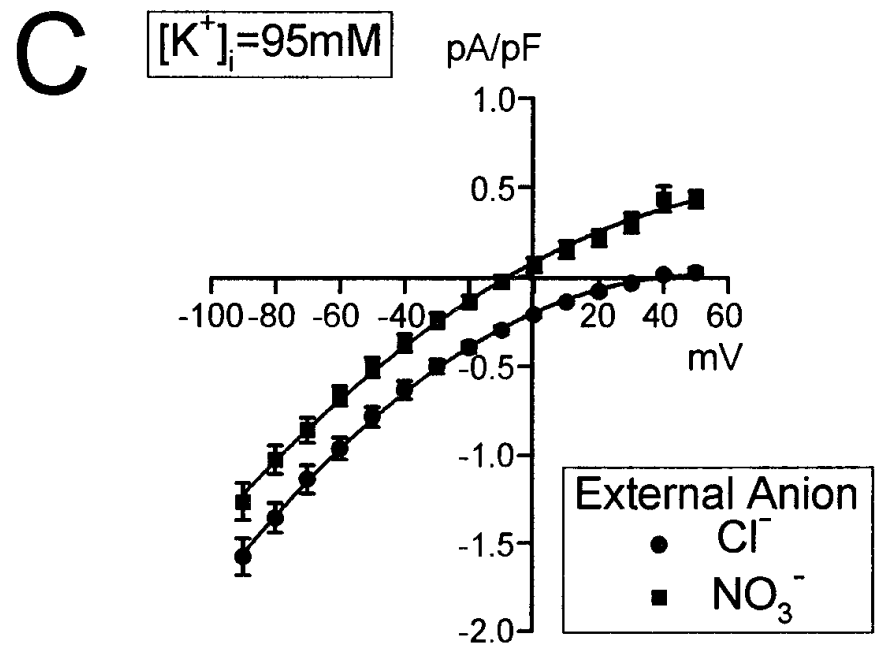

D

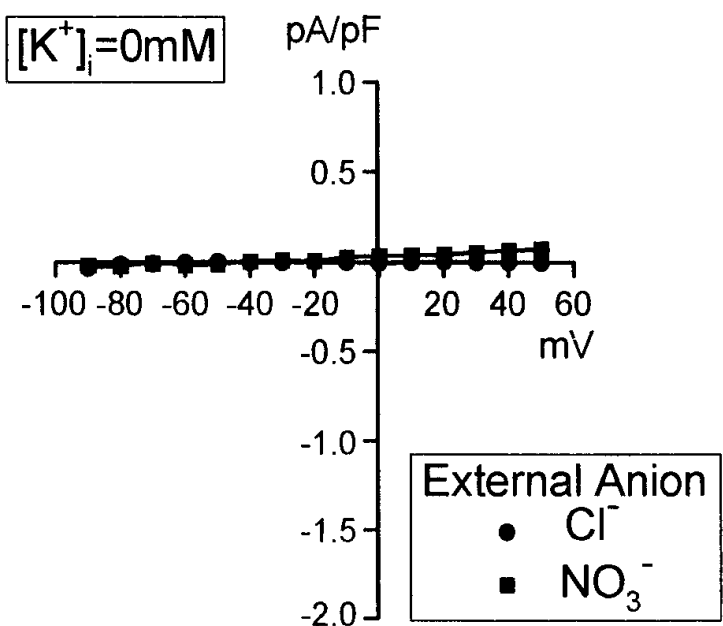

Figure 3. $\left[\mathrm{Na}^{+}\right]_{\mathrm{o}}$ and $\left[\mathrm{K}^{+}\right]_{\mathrm{i}}$ dependence of anion conductance activation evoked by $200 \mu \mathrm{M}$ glutamate. $A$, Glutamate-evoked currents at $0 \mathrm{mV}$ with $\mathrm{ClO}-\mathrm{O}_{4}^{-}$ as the external anion (solutions as in Fig. 2) and with external sodium present (left) or absent (right; replaced by choline, conducted on 5 cells). $B$, Average $I-V$ data from experiments as in $A$ on three cells. Sodium removal abolishes both the outward current at positive potentials (produced by $\mathrm{ClO}_{4}^{-}$entry through the anion conductance of the carriers) and the inward current at negative potentials (primarily current produced by the cotransport into the cell of a net positive charge with each glutamate anion). Similar results were obtained in four cells when $\mathrm{NO}_{3}^{-}$was the external anion. $C, D$, Mean $I-V$ relations (normalized by cell capacitance) for currents evoked by $200 \mu \mathrm{M}$ glutamate, with $\mathrm{K}^{+}$either present $(C, 5$ cells) or omitted ( $D, 5$ cells) from the pipette and with $50 \mathrm{mM} \mathrm{NO}_{3}^{-}$either present in (curves labeled $\mathrm{NO}_{3}^{-}$) or absent from (curves labeled $\mathrm{Cl}^{-}$) the external solution. Pipette and external solutions are described in Materials and Methods.

anion (because glutamate uptake is absolutely dependent on the countertransport of $\mathrm{K}^{+}$), and the outward current produced at $+40 \mathrm{mV}$ with $\mathrm{NO}_{3}^{-}$present was reduced by $86 \pm 3 \%$ (5 cells studied with and 5 without $\mathrm{K}^{+}$in the pipette). Thus, activation of the anion conductance shows a similar ionic dependence to that for activation of glutamate transport.

\section{The anion conductance can be activated by intracellular glutamate}

With sodium and glutamate present inside the cell, raising the external potassium concentration evokes an outward membrane current, which is attributed to reversed operation of the uptake carrier, transporting glutamate and net positive charge out of the cell (Szatkowski et al., 1990). Experiments described below (Fig. 6; Billups and Attwell, 1996) confirm that glutamate is released from the cell by reversed uptake in this situation.

When the external $\mathrm{Cl}^{-}$was replaced by $\mathrm{NO}_{3}^{-}$or $\mathrm{ClO}_{4}^{-}$, the outward current evoked by a rise of $\left[\mathrm{K}^{+}\right]_{\mathrm{o}}$ was increased (Fig.
$4 A, C)$, the mean increase being by a factor of $1.58 \pm 0.06$ (SEM; 6 cells) for $\mathrm{NO}_{3}^{-}$and by $3.34 \pm 0.41$ (5 cells) for $\mathrm{ClO}_{4}^{-}$. Experiments described below (Fig. 6) show that there is no increase in the glutamate release by reversed uptake when $\mathrm{Cl}^{-}$is replaced in this way. Furthermore, when sodium and glutamate were omitted from the pipette (replaced with choline- $\mathrm{Cl}$ ), raising $\left[\mathrm{K}^{+}\right]_{\mathrm{o}}$ evoked no current in cells superfused with $\mathrm{NO}_{3}^{-}$solution (mean current/ capacitance was $0.49 \pm 0.08 \mathrm{pA} / \mathrm{pF}$ in 5 cells with $\mathrm{Na}$-glu inside and $-0.05 \pm 0.03 \mathrm{pA} / \mathrm{pF}$ in 5 cells with Na-glu omitted), as found by Szatkowski et al. (1990) with $\mathrm{Cl}^{-}$outside, indicating that the extra $\mathrm{K}^{+}$-evoked outward current seen during $\mathrm{Cl}^{-}$substitution is generated by the glutamate transporter. We therefore attribute the extra outward current to an influx of $\mathrm{NO}_{3}^{-}$or $\mathrm{ClO}_{4}^{-}$through the anion conductance of the carrier, with the anion conductance being activated when reversed operation of the carrier is evoked by the simultaneous presence of intracellular glu ${ }^{-}$and $\mathrm{Na}^{+}$and extracellular $\mathrm{K}^{+}$. When activated by reversed uptake, the selec- 


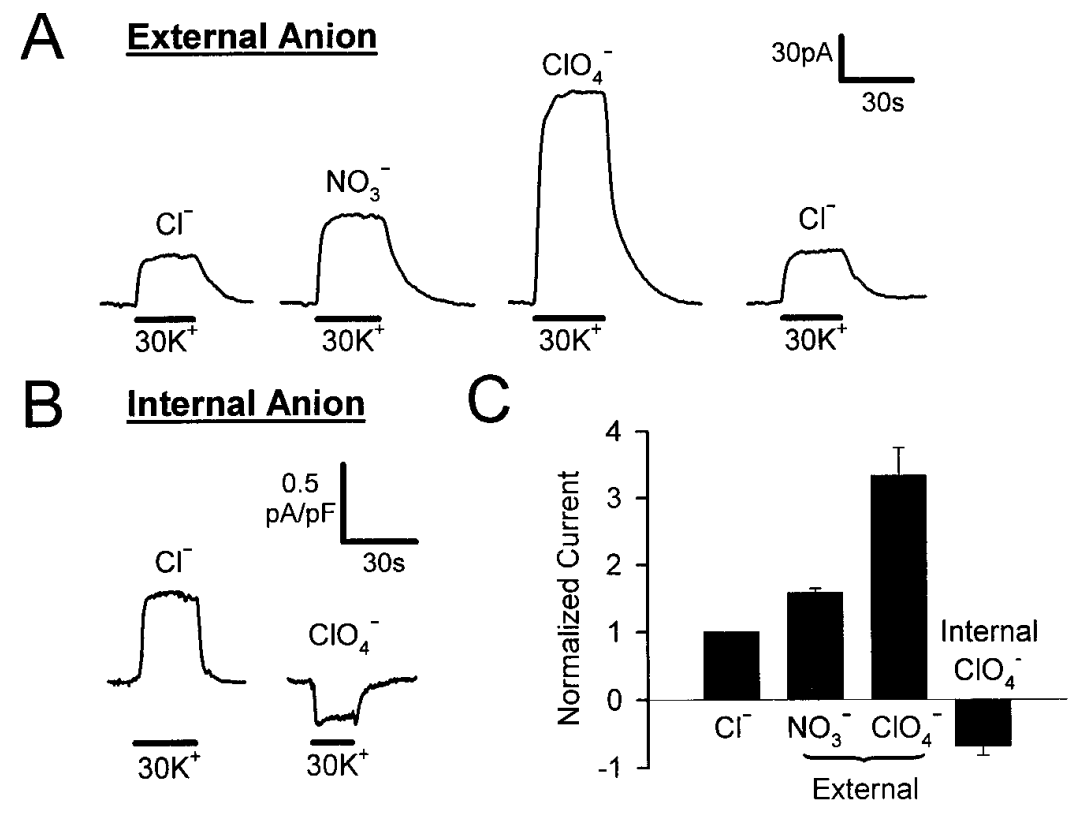

Figure 4. Activation of the anion conductance during reversed uptake evoked by raising $\left[\mathrm{K}^{+}\right]_{\mathrm{o}}$ from 0 to $30 \mathrm{~mm}$ (black bars) around cells whole-cell-clamped with solutions containing $10 \mathrm{~mm}$ Na-glu. $A, \mathrm{~K}^{+}$-evoked currents at $0 \mathrm{mV}$ in a Müller cell bathed sequentially in external solutions containing $\mathrm{Cl}^{-}$as the main anion, including $50 \mathrm{mM} \mathrm{NO}_{3}^{-}$or $\mathrm{ClO}_{4}^{-}$, and then with just $\mathrm{Cl}^{-}$again. External solution as in Figure $3 C$ and with $30 \mathrm{~mm}$ choline- $\mathrm{Cl}$ replaced by $\mathrm{KCl}$ when $\left[\mathrm{K}^{+}\right]$was raised. Pipette solution for reversed uptake as in Materials and Methods. $B, \mathrm{~K}^{+}$-evoked currents in two different cells (normalized by cell capacitance) clamped with pipette solutions (see Materials and Methods) containing either $\mathrm{Cl}^{-}$or $\mathrm{ClO}_{4}^{-}$as the main anion. External solution as in $A$ for $\mathrm{Cl}^{-} . C$, Mean $( \pm \mathrm{SEM}) \mathrm{K}^{+}$-evoked currents measured as in $A$ and $B$ for six cells with external $\mathrm{NO}_{3}^{-}$, for five with external $\mathrm{ClO}_{4}^{-}$, and for five cells clamped with internal $\mathrm{ClO}_{4}^{-}$(normalized to 3 cells clamped with internal $\mathrm{Cl}^{-}$).

tivity sequence of the anion conductance for different anions is $\mathrm{ClO}_{4}^{-}>\mathrm{NO}_{3}^{-}>\mathrm{Cl}^{-}$, as was found above for activation of the conductance by transport of glutamate into the cell.

Conversely, when the $\left[\mathrm{K}^{+}\right]_{\mathrm{o}}$ was raised around cells containing $50 \mathrm{~mm}$ intracellular $\mathrm{ClO}_{4}^{-}$(replacing $\mathrm{Cl}^{-}$), instead of an outward current being evoked, an inward current shift occurred (Fig. $4 B, C)$, presumably because activation of the anion conductance leads to an efflux of $\mathrm{ClO}_{4}^{-}$, generating an inward current that is larger than the outward transport current produced by glutamate efflux.

These data show that the anion conductance can be activated by extracellular or intracellular glutamate, provided that the transport part of the molecule is allowed to cycle by provision of $\mathrm{Na}^{+}$ and $\mathrm{K}^{+}$on appropriate sides of the membrane. A kinetic scheme consistent with these observations is presented in Discussion (Fig. 7). The following section provides evidence that the anion conductance can also be activated when the transport activity of the carrier molecule is greatly reduced.

\section{Anion conductance activation in the absence of net glutamate transport}

In the absence of intra- and extracellular $\mathrm{K}^{+}$, forward and reversed transport of glutamate are inhibited (Kanner and Sharon, 1978; Barbour et al., 1988; Szatkowski et al., 1990; Billups and Attwell, 1996) (homoexchange of glutamate can still occur: Kanner and Bendahan, 1982). Figure $3 D$ shows that external glutamate does not evoke a detectable current when $\mathrm{Cl}^{-}$is the main intra- and extracellular anion present. However we found that, with net glutamate transport abolished in this way, if glutamate and sodium were present inside the cell (via the whole-cell pipette), addition of extracellular glutamate did evoke a current. This current was inward at negative and outward at positive potentials and showed the pharmacology of the uptake carrier (Fig. 5A). Activation of this current was dependent on the presence of both glutamate and sodium inside the cell (Fig. $5 B$ ). Relative values of glutamate-evoked current (normalized to cell capacitance) at $+20 \mathrm{mV}$ with $10 \mathrm{~mm} \mathrm{Na-glu}, 10 \mathrm{~mm}^{-} \mathrm{glu}^{-}$but no $\mathrm{Na}^{+}, 10 \mathrm{mM} \mathrm{Na}^{+}$but no $\mathrm{glu}^{-}$, or no $\mathrm{Na}^{+}$and no $\mathrm{glu}^{-}$in the pipette, were, respectively, 1.0, $0.014 \pm 0.024,-0.041 \pm 0.031$, and $0.0 \pm 0.0$ ( 6 or 7 cells for each pipette solution).
Changing the external chloride concentration revealed that the current was produced by activation of an anion conductance (Fig. $5 C, D)$, although the absolute value of the reversal potential for the current and its less-than-Nernstian dependence on $\left[\mathrm{Cl}^{-}\right]_{\mathrm{o}}$ indicated that this conductance was not very specific for $\mathrm{Cl}^{-}$. Interestingly, Vandenberg and colleagues (1995) have shown the presence of a $\mathrm{Cl}^{-}$-dependent cation leak through a cloned human glutamate transporter, and, if present in the salamander transporter, this might explain the lack of a Nernstian dependence on $\left[\mathrm{Cl}^{-}\right]_{\mathrm{o}}$ in Figure $5 \mathrm{D}$. With $\mathrm{ClO}_{4}^{-}$instead of $\mathrm{Cl}^{-}$as the major anion present inside and outside the cell (Fig. $5 E$ ), the glutamateevoked conductance was greatly increased (in 4 cells the currents evoked at -80 and $+40 \mathrm{mV}$ were increased by factors of $30.1 \pm$ 6.5 and $9.7 \pm 1.8$, respectively: the fact that the reversal potential was near $-10 \mathrm{mV}$ instead of $0 \mathrm{mV}$ with $50 \mathrm{~mm} \mathrm{ClO}_{4}^{-}$in the pipette and outside the cell may reflect incomplete dialysis of the cell with $\mathrm{ClO}_{4}^{-}$). A similar, but smaller increase in the outward current at positive potentials was seen with $\mathrm{NO}_{3}^{-}$outside the cell (data not shown). The increase in current when $\mathrm{Cl}^{-}$was replaced by $\mathrm{NO}_{3}^{-}$ or $\mathrm{ClO}_{4}^{-}$is consistent with the selectivity sequence described above for the anion conductance evoked during forward or reversed transport of glutamate.

From these data, it seems that the anion conductance can be activated even when the carrier molecule is not producing net transport of glutamate across the membrane. We took advantage of this to investigate the external glutamate and sodium dependence of anion conductance activation without contamination from current generated by glutamate transport. With $100 \mathrm{~mm}$ $\mathrm{NO}_{3}^{-}$outside the cell, the anion conductance (assessed as the outward current at $+20 \mathrm{mV}$ ) showed a Michaelis-Menten dependence on external glutamate concentration, with a $K_{\mathrm{m}}$ (mean value $15.1 \pm 0.3 \mu \mathrm{M}$ in 5 cells) similar to that found for the glutamate transport current (Barbour et al., 1991; Eliasof and Jahr, 1996). Varying the external sodium concentration (replaced with choline; 5 cells) revealed a sigmoid dependence on $\left[\mathrm{Na}^{+}\right]_{\mathrm{o}}$ at low $\left[\mathrm{Na}^{+}\right]_{\mathrm{o}}$ (rising as $\left[\mathrm{Na}^{+}\right]_{\mathrm{o}}^{2.5}$ for $\left[\mathrm{Na}^{+}\right]_{\mathrm{o}} \leq 15 \mathrm{~mm}$ at $-40 \mathrm{mV}$ ), similar to that for the current associated with glutamate transport (Barbour et al., 1991). These data are consistent with one glutamate anion and two $\mathrm{Na}^{+}$ions having to bind to activate the anion 


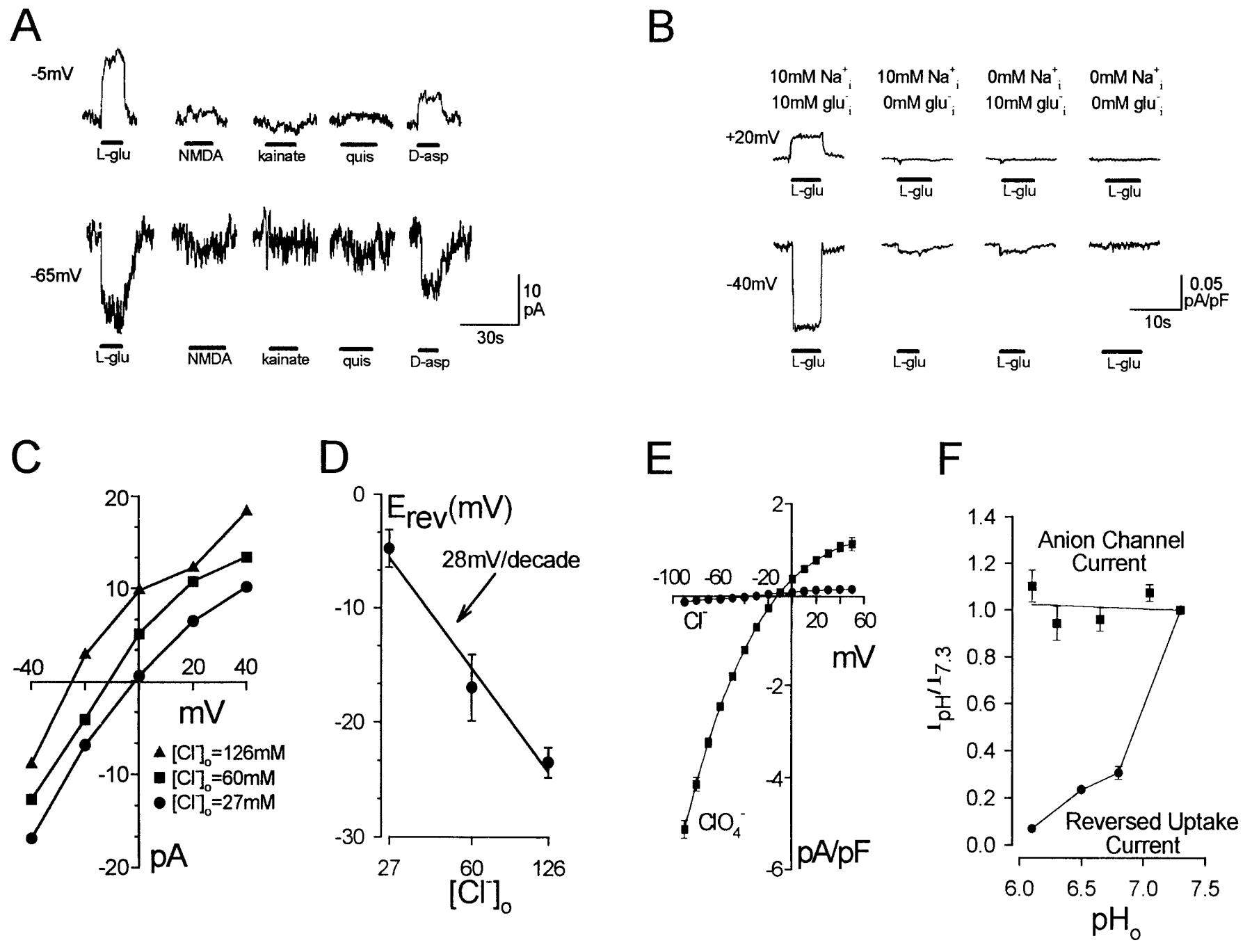

Figure 5. Activation of the anion conductance with glutamate transport inhibited by the absence of extra- and intracellular $\mathrm{K}^{+}$and with $\mathrm{Na}^{+}$and glu ${ }^{-}$ added intracellularly. $A$, Currents evoked at -5 and $-65 \mathrm{mV}$ by $100 \mu \mathrm{M}$ glutamate and analogs. Pipette and external solution are described in Materials and Methods. Analogs that activate non-NMDA, NMDA, and metabotropic receptors produced no current change. Glutamate and D-aspartate (also transported on uptake carriers) evoked a conductance increase. $B$, Specimen glutamate-evoked currents (normalized by cell capacitance) as in $A$ but with varying $\left[\mathrm{Na}^{+}\right]$and $\left[\mathrm{glu}^{-}\right]$in the pipette. $C$, Specimen $I-V$ data from one cell as in $A$ with varying external $\left[\mathrm{Cl}^{-}\right]$. External solution as in $A$, but with no ouabain, with choline-Cl replaced by $7 \mathrm{~mm} \mathrm{NaCl}$, and $\mathrm{Cl}^{-}$replaced by gluconate as needed. Internal solution as in Figure $4 A$. $D$, The reversal potential of data obtained as in $C$ (data from $5-8$ cells/point) changes by $28 \mathrm{mV}$ per 10 -fold change of $\left[\mathrm{Cl}^{-}\right]_{\mathrm{o}} . E, I-V$ data (normalized by cell capacitance) obtained as in $A$ from five cells with $\mathrm{Cl}^{-}$and five cells with $\mathrm{ClO}_{4}^{-}$as the main internal and external anion. With $\mathrm{ClO}_{4}^{-}$the mean $\pm \mathrm{SEM}$ outward current at +20 $\mathrm{mV}$ was $122 \pm 14 \mathrm{pA}$. External solutions as Figure $3 C$, but with $\mathrm{ClO}_{4}^{-}$replacing $\mathrm{NO}_{3}^{-}$; pipette solution as Figure $4 B . F$, Dependence on external $\mathrm{pH}(\mathrm{pH}$ ) of the anion conductance current for five cells studied as in $A$ (current evoked by $1 \mathrm{~mm}$ glutamate at $-40 \mathrm{mV}$, squares). Pipette solution as Figure $4 A$; external solution as for $\mathrm{Cl}^{-}$in Figure $3 C$. For comparison, we show the $\mathrm{pH}_{\mathrm{o}}$ dependence of the reversed uptake current (at $0 \mathrm{mV}$, circles) produced by raising $\left[\mathrm{K}^{+}\right]$from 0 to $30 \mathrm{~mm}$ with $10 \mathrm{mM} \mathrm{glu}^{-}$and $20 \mathrm{mM} \mathrm{Na}^{+}$in the pipette (Billups and Attwell, 1996).

conductance-a result that is incorporated into a kinetic scheme proposed in Discussion.

With $\mathrm{Na}^{+}$and $\mathrm{glu}^{-}$inside the cell, the reversed uptake current produced by raising $\left[\mathrm{K}^{+}\right]_{\mathrm{o}}$ is greatly reduced when the extracellular $\mathrm{pH}$ is made acid (Billups and Attwell, 1996), presumably because with an acid $\mathrm{pH}_{\mathrm{o}}$ there is not enough $\mathrm{OH}^{-}$ present for countertransport into the cell (or because the carrier cannot lose $\mathrm{H}^{+}$cotransported out of the cell). An acid extracellular $\mathrm{pH}$ had no effect, however, on the anion conductance activated by adding external glutamate with $\mathrm{glu}^{-}$and $\mathrm{Na}^{+}$inside the cell (and no $\mathrm{K}^{+}$inside or outside; Fig. $5 F$ ), again suggesting that it is possible to dissociate the anion conductance function of the molecule from its glutamatetransporting activity. A kinetic model consistent with this observation is presented in Discussion.

\section{Lack of coupling of anion movements to glutamate transport}

To determine whether alteration of the ion flux through the anion conductance part of the transporter molecule has any effect on the rate of glutamate transport, we evoked reversed uptake in salamander retinal glial cells while monitoring glutamate release with non-NMDA receptor channels in isolated rat Purkinje cells placed just outside the glial cells (Billups and Attwell, 1996).

Glutamate release by reversed uptake was evoked with $10 \mathrm{~mm}$ $\mathrm{Na}$-glu in the glial cell and $30 \mathrm{~mm} \mathrm{~K}^{+}$in the extracellular solution by depolarizing the cell from $-60 \mathrm{mV}$ (at which potential glutamate release by reversed uptake is small; Szatkowski et al., 1990; Billups and Attwell, 1996) to $+20 \mathrm{mV}$. This procedure produced a current in the adjacent Purkinje cell consistent with glutamate 


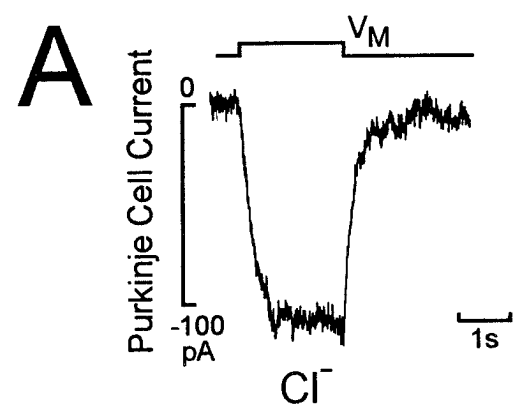

$\mathrm{B}$

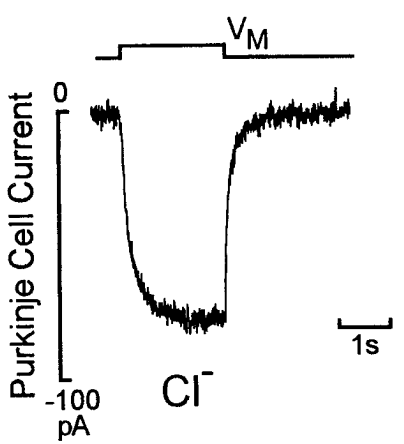

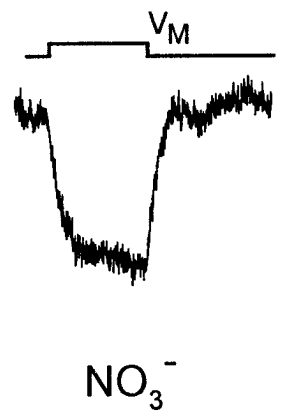

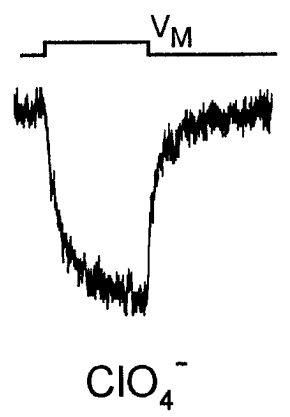

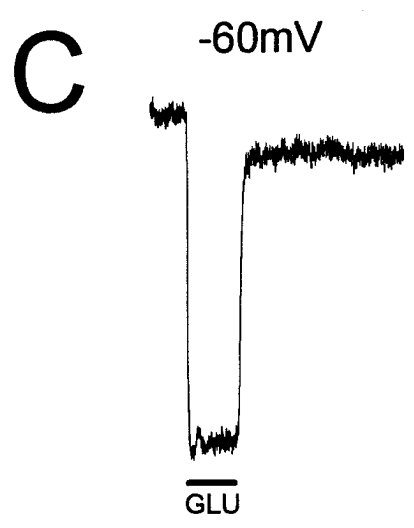
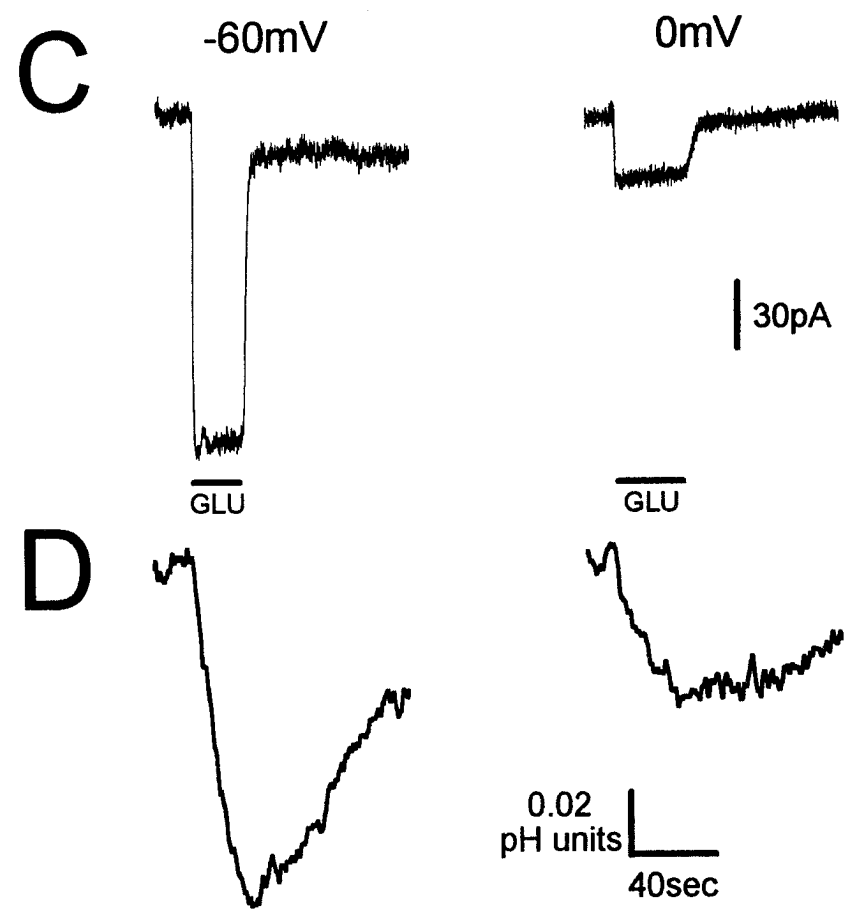

Figure 6. Investigation of coupling of anion movements to glutamate transport. $A, B$, Test of whether increasing current flow through the anion conductance increases glutamate transport. $A$, Currents evoked in a Purkinje cell (clamped to $-60 \mathrm{mV}$ ) by glutamate released from an adjacent Müller cell by reversed uptake in external solution containing $\mathrm{Cl}^{-}$(left) or $\mathrm{NO}_{3}^{-}$(right) as the main anion. Reversed uptake was evoked by bathing the cells in $30 \mathrm{~mm} \mathrm{~K}^{+}$solution (as in Fig. $3 C$ with $\mathrm{KCl}$ replacing choline-Cl) and stepping the Müller cell voltage from -60 to $+20 \mathrm{mV}$ (top trace). The decrease in the Purkinje cell current response in $\mathrm{NO}_{3}^{-}$is produced by a decrease in glutamate sensitivity of the non-NMDA receptors of the Purkinje cell and not by a decrease of glutamate release from the Müller cell (see text). Purkinje cell pipette solution as described in Materials and Methods; Müller cell pipette solution for reversed uptake as described in Materials and Methods. $B$, Same experiment as in $A$ but testing the effect of external $\mathrm{ClO}_{4}^{-}$. The glutamate sensitivity of the Purkinje cell is more than doubled by $\mathrm{ClO}_{4}^{-}$(see text), so the small decrease of response seen here implies a large decrease of glutamate release from the Müller cell. $C, D$, Test of whether $\mathrm{H}^{+} / \mathrm{OH}^{-}$movements on the uptake carrier are through the anion conductance and are passive or are coupled to glutamate transport. $C$, Membrane currents evoked at -60 and $0 \mathrm{mV}$ by $200 \mu \mathrm{M}$ glutamate in a Müller cell clamped with standard internal solution, pH 7.0, but containing only $0.5 \mathrm{mM}$ HEPES and also $100 \mu \mathrm{M}$ BCECF. Standard external solution was used but with its pH adjusted to 7.7. $D$, Glutamate-evoked changes in intracellular $\mathrm{pH}$, measured at the same time as the current records in $C$, are acid both below and above the reversal potential for $\mathrm{H}^{+} / \mathrm{OH}^{-}$, implying coupling of the movement of $\mathrm{H}^{+} / \mathrm{OH}^{-}$to glutamate transport.

release by reversed uptake activating non-NMDA channels (Billups and Attwell, 1996). Replacing external $\mathrm{Cl}^{-}$with $\mathrm{NO}_{3}^{-}$or $\mathrm{ClO}_{4}^{-}$increased the outward current shift evoked in the glial cell by a rise of $\left[\mathrm{K}^{+}\right]_{\mathrm{o}}$ at $0 \mathrm{mV}$ (Fig. $4 A$ ), because $\mathrm{NO}_{3}^{-}$and $\mathrm{ClO}_{4}^{-}$can enter the cell through the anion conductance better than $\mathrm{Cl}^{-}$can but had little effect on the change of membrane current evoked in the Purkinje cell by glutamate release from the glial cell (Fig. $6 A, B)$. On average, the responses with $50 \mathrm{~mm}$ external $\mathrm{NO}_{3}^{-}$or $\mathrm{ClO}_{4}^{-}$present were $0.69 \pm 0.04$ ( 3 cells) and $0.98 \pm 0.10$ ( 6 cells) of those in external $\mathrm{Cl}^{-}$. Control experiments, in which the sensitivity of three Purkinje cells to $3 \mu \mathrm{M}$ glutamate was tested, showed that $\mathrm{NO}_{3}^{-}$reduced the current evoked in the Purkinje cell to $0.76 \pm 0.18$ of its value in $\mathrm{Cl}^{-}$, whereas $\mathrm{ClO}_{4}^{-}$increased it to $2.33 \pm 0.29$ (data not shown). The increased current in $\mathrm{ClO}_{4}^{-}$is consistent with the fact that chaotropic ions like $\mathrm{ClO}_{4}^{-}$increase the affinity of AMPA receptors (Honore and Drejer, 1988). Combining these alterations of glutamate sensitivity with the data in Figure 6, $A$ and $B$, suggests that in the presence of $\mathrm{NO}_{3}^{-}$(which increases the glial cell current evoked by a rise of $\left[\mathrm{K}^{+}\right]_{\mathrm{o}}$ by a factor of 1.58; Fig. 4) glutamate release is essentially unaffected $(0.91 \pm$ 0.22 of its value in $\mathrm{Cl}^{-}$), whereas in $\mathrm{ClO}_{4}^{-}$(which increases the $\mathrm{K}^{+}$-evoked current in the glial cell 3.34-fold) glutamate release is actually reduced to $0.42 \pm 0.06$ of its value in $\mathrm{Cl}^{-}$. Clearly, the amount of glutamate transported is not proportional to the move- ment of charge through the anion conductance part of the carrier molecule, as was suggested also by the experiments above in which anion conductance activation was still seen in the absence of $\mathrm{K}^{+}$ and at positive potentials when transport is inhibited.

\section{Coupling of movement of $\mathrm{pH}$-changing ions to glutamate transport}

Changes of $\mathrm{pH}$ produced by glutamate uptake carriers have been attributed previously to a cotransport of $\mathrm{H}^{+}$ions with glutamate or to a countertransport of $\mathrm{OH}^{-}$ions (Erecinska et al., 1983; Bouvier et al., 1992)-interpretations that imply that glutamate accumulation is powered partly by the transmembrane $\mathrm{pH}$ gradient. However, if glutamate transporters contain an anion conductance, an obvious possibility is that the $\mathrm{pH}$ changes are generated by passive movement of $\mathrm{OH}^{-}$ions through the anion conductance, not coupled to the transport of glutamate. To investigate this possibility, we measured changes of intracellular $\mathrm{pH}$ evoked by external glutamate in Müller cells clamped to different potentials. For this experiment the intra- and extracellular solutions had $\mathrm{pH}$ values of 7.0 and 7.7, respectively, giving a reversal potential for $\mathrm{OH}^{-}$of $-41 \mathrm{mV}$. Thus, at potentials more positive than -41 $\mathrm{mV}$, if $\mathrm{OH}^{-}$were moving passively through the glutamate-evoked anion conductance, it would move into the cell, making the cell more alkaline, whereas if movement of $\mathrm{OH}^{-} / \mathrm{H}^{+}$were coupled 
thermodynamically to glutamate entry, then glutamate should make the cell go acid at all potentials. Experimentally, the latter was found to be the case (Fig. $6 C, D$ ). Indeed, at $0 \mathrm{mV}$ the ratio of the rate of acidification to the glutamate-evoked current was similar to that at $-60 \mathrm{mV}(0.27 \pm 0.04$ and $0.23 \pm 0.05 \mathrm{pH}$ units/sec per $\mathrm{nA}$ at $0 \mathrm{mV}$ and $-60 \mathrm{mV}$, respectively, in 6 cells: the slightly, although not significantly, smaller value at $-60 \mathrm{mV}$ might be expected because the inward glutamate-evoked current, but not the $\mathrm{pH}$ change, is increased by chloride efflux through the anion conductance). Thus, the movement of $\mathrm{pH}$-changing ions is coupled to glutamate transport, rather than occurring through the anion conductance.

\section{DISCUSSION}

\section{The salamander glial cell glutamate transporter has an anion conductance}

Data presented here show that the glutamate transporter in salamander retinal glial cells activates an anion conductance (see also Eliasof and Jahr, 1996). Removing external chloride increases, and lowering internal chloride decreases, the glutamateevoked inward current, consistent with the results of Wadiche et al. (1995) on cloned mammalian transporters. With $\mathrm{Cl}^{-}$as the main anion inside and outside the cell, the glutamate-evoked current remains inward at positive potentials (Fig. 1), presumably because it is dominated by the current associated with glutamate transport rather than that generated by the anion conductance. The contribution of the anion conductance can be greatly enhanced by replacing $\mathrm{Cl}^{-}$with more permeant anions, resulting in the glutamate-evoked current becoming outward at positive potentials (Fig. 2). Inspection of the data in Figures 2, $C$ and $E$, and 4 of this paper and in Bouvier et al. (1992), suggests a selectivity sequence $\mathrm{SCN}^{-}>\mathrm{ClO}_{4}^{-}>\mathrm{NO}_{3}^{-}>\mathrm{Cl}^{-} \simeq \mathrm{Br}^{-} \simeq \mathrm{I}^{-}$for the anion conductance. This is similar to the theoretical sequence 1 of Wright and Diamond (1977) but differs in that, for sequence 1, $\mathrm{ClO}_{4}^{-}>\mathrm{SCN}^{-}$and $\mathrm{I}^{-}>\mathrm{Br}^{-}>\mathrm{Cl}^{-}$. The apparent position of $\mathrm{ClO}_{4}^{-}$in our selectivity sequence could, however, be altered by the fact that $\mathrm{ClO}_{4}^{-}$, in addition to permeating the anion conductance, seems to slow carrier cycling (see Lack of Coupling of Anion Movements to Glutamate Transport) and so may reduce opening of the anion conductance. Conceivably, the selectivity sequence of the anion conductance would be identical to sequence 1 of Wright and Diamond (1977) if currents through the open anion conductance could be investigated independently of changes in conductance activation. In earlier work, Barbour and colleagues (1991) observed a small (12\%, but statistically insignificant) decrease of glutamate-evoked current on removing internal chloride, as we report here, but did not see the effect of removing external chloride shown in Figure 1. This may be attributable to the use of a nonsaturating glutamate dose or to the presence of acetate in the internal solution in the experiments of Barbour et al. (1991); we are performing experiments to examine these possibilities.

\section{Different modes of gating of the anion conductance}

The glutamate carrier anion conductance can be activated by the simultaneous presence of extracellular glutamate and sodium and intracellular potassium when the carrier operates in forward uptake mode (Figs. 1-3). However, it is also activated by the simultaneous presence of intracellular glutamate and sodium and extracellular potassium when the carrier transports glutamate out of the cell (Fig. 4). These data suggest that activation of the anion conductance may occur when a particular state of the carrier cycle is reached, independent of

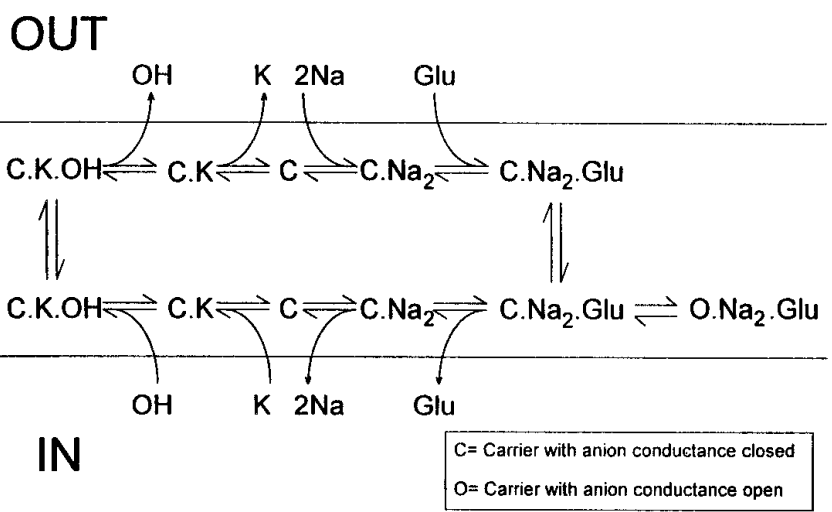

Figure 7. A possible kinetic scheme for the glutamate transporter and associated anion conductance. $C$ denotes the carrier in conformations for which the anion conductance is not activated (closed). In these conformations the carrier can bind extracellular glu ${ }^{-}$and two $\mathrm{Na}^{+}$ions, transport them to the inner face of the membrane, then bind $\mathrm{K}^{+}$and $\mathrm{OH}^{-}$at the inner membrane surface and transport them to the outside of the cell, shifting one net positive charge into the cell during the carrier cycle. (Note that the order in which $\mathrm{K}^{+}$and $\mathrm{OH}^{-}$bind is unknown. Furthermore, although we show $\mathrm{OH}^{-}$countertransport out of the cell, as discussed in the text the carrier might get energy from the transmembrane $\mathrm{pH}$ gradient by cotransporting $\mathrm{H}^{+}$with glu ${ }^{-}$). $O$ denotes a conformation of the transporter in which the anion conductance is open. Here we postulate simply that the open state can be accessed from the closed conformation that has $\mathrm{Na}^{+}$and glu $^{-}$bound at the inner face of the membrane. Our data would also be consistent with an $O$ state being accessed from the closed conformation with $\mathrm{Na}^{+}$and glu ${ }^{-}$bound at the outer membrane surface (or from both of the C.Na $a_{2}$ Glu conformations).

whether that state is reached by the carrier cycling in the forward or the reversed direction. A possible example of such a scheme is shown in Figure 7.

If the anion conductance only opens once each carrier cycle (during forward uptake), its open probability could be larger at negative potentials when the carrier cycles more rapidly. This might explain why the change in glutamate-evoked current produced by removing external $\mathrm{Cl}^{-}$is larger at more negative potentials (Fig. 1) rather than at positive potentials when the driving force for $\mathrm{Cl}^{-}$entry is greatest; similarly, it would explain why the outward shift of glutamate-evoked current produced by external $\mathrm{ClO}_{4}^{-}$or $\mathrm{NO}_{3}^{-}$is only slightly larger at positive potentials (Fig. 2).

One constraint on which state of the carrier cycle allows activation of anion conductance is provided by the observation that the anion conductance can be activated (Fig. 5) when net glutamate transport is inhibited by the absence of intra- and extracellular $\mathrm{K}^{+}$. This implies that the anion conductance is activated by a state of the carrier cycle at which the carrier does not have $\mathrm{K}^{+}$ bound. If, as suggested by Kanner and Bendahan (1982) and as shown in Figure 7, the $\mathrm{K}^{+}$translocating part of the carrier cycle is distinct from the $\mathrm{Na}^{+}$and $\mathrm{glu}^{-}$translocating part of the cycle, then activation of the anion conductance must occur from one of the states of the glu ${ }^{-} / \mathrm{Na}^{+}$transporting limb of the carrier cycle. The observation (see Anion Conductance Activation in the Absence of Net Glutamate Transport) that anion conductance activation shows a first-order dependence on external glutamate concentration and a sigmoid dependence on $\left[\mathrm{Na}^{+}\right]_{\mathrm{o}}$ implies it occurs from a state with one glu ${ }^{-}$and two $\mathrm{Na}^{+}$ions bound (Fig. 7). When intra- and extracellular $\mathrm{K}^{+}$are absent, the anion conductance is activated by external glutamate only if glutamate and sodium are present intracellularly (Fig. $5 B$ ); this could be explained by binding of the internal glutamate and sodium resulting 
in the carrier spending more time in the state with $\mathrm{glu}^{-}$and two $\mathrm{Na}^{+}$ions bound that is suggested in Figure 7 to lead to anion conductance activation. (Similarly, external glutamate is needed to prevent the carrier accumulating in the state at the external surface with $\mathrm{Na}^{+}$bound but with no glutamate bound.) Figure 7 proposes that the $\mathrm{OH}^{-} / \mathrm{H}^{+}$transporting part of the carrier cycle is associated with the $\mathrm{K}^{+}$transporting limb of the cycle rather than with the $\mathrm{glu}^{-} / \mathrm{Na}^{+}$transporting limb. This would explain the fact that an acid $\mathrm{pH}$ (equivalent to lack of transported substrate $\mathrm{OH}^{-}$in Fig. 7) does not affect the activation of the anion conductance seen in the absence of intra- and extracellular $\mathrm{K}^{+}$(Fig. $5 F$ ), although it does block reversed uptake of glutamate (Billups and Attwell, 1996).

The data in Figure 6, $A$ and $B$, suggest that there is no energetic coupling between the anion flux through the conformation of the carrier denoted $\mathrm{O}$ in Figure 7 and the cycle of reactions that transport glutamate.

\section{Reinterpretation of the effects of intracellular $\mathrm{ClO}_{4}^{-}$ and $\mathrm{NO}_{3}^{-}$}

Bouvier and colleagues (1992) found that intracellular $\mathrm{ClO}_{4}^{-}$and $\mathrm{NO}_{3}^{-}$increased the inward current evoked by external glutamate, that $\mathrm{ClO}_{4}^{-}$came out of the cell when glutamate was applied, and that the presence of these ions intracellularly reduced the ratio of the $\mathrm{pH}$ change generated by the carrier to the current that it generated. Those results were interpreted as showing that the glutamate-evoked $\mathrm{pH}$ changes were generated by the transport of $\mathrm{OH}^{-}$ions out of the cell and that $\mathrm{ClO}_{4}^{-}$and $\mathrm{NO}_{3}^{-}$could compete for transport at the $\mathrm{OH}^{-}$site. It is now clear that the effects of $\mathrm{ClO}_{4}^{-}$and $\mathrm{NO}_{3}^{-}$were produced by these ions leaving the cell (at a much higher rate than $\mathrm{Cl}^{-}$) through the anion conductance associated with the uptake carrier, generating an extra inward current. This invalidates the earlier conclusion that the $\mathrm{pH}$ changes generated by the carrier are produced by the transport of $\mathrm{OH}^{-}$out of the cell rather than the (thermodynamically equivalent) transport of $\mathrm{H}^{+}$into the cell: our data reopen the possibility that $\mathrm{H}^{+}$is cotransported with glutamate.

Figure $6 D$ shows that, irrespective of whether $\mathrm{OH}^{-}$or $\mathrm{H}^{+}$is transported, movement of the $\mathrm{pH}$-changing ion is coupled to glutamate transport. Thus, glutamate uptake does derive energy from the transmembrane $\mathrm{pH}$ gradient, consistent with the observation that, in the kidney, a $\mathrm{pH}$ gradient alone can drive uptake (Nelson et al., 1983).

\section{Therapeutic possibilities offered by the existence of the anion conductance}

Our demonstration that the anion conductance part of the transporter molecule can be activated even when glutamate transport is inhibited (at positive potentials in Fig. 2 and in the absence of $\mathrm{K}^{+}$in Fig. 5) suggests some independence between these two functions of the molecule and, hence, that they may be capable of being modulated separately by pharmacological agents. This suggests a possible strategy for developing drugs to treat conditions in which excessive glutamate is released, such as epilepsy. If, for glutamate transporters in presynaptic terminals, the anion conductance activation could be greatly enhanced, then whenever glutamate was released, activation of the anion conductance during glutamate re-uptake would tend to clamp the presynaptic terminal at a negative potential, reducing further exocytotic release (by making it harder for action potentials to invade the synaptic terminal) and potentiating the (voltage-dependent) reuptake. Interestingly, in the retina at least, the glutamate trans- porter in cone synaptic terminals expresses a particularly large anion conductance (Sarantis et al., 1988, Eliasof and Werblin, 1993), like the human EAAT4 carrier (Fairman et al., 1995), suggesting that evolution already might have arrived at this strategy for controlling glutamate release. Recently Rothstein and colleagues (1996) have shown that preventing the expression of neuronal EAAC-1 carriers leads to epileptic behavior of neurons (whereas preventing expression of glial uptake carriers leads to a rise of extracellular glutamate concentration but no epilepsy). It is not yet known whether the antiepileptic properties of EAAC-1 transporters derive solely from their ability to take up glutamate or whether their contribution to the anion conductance of neurons is also involved.

During ischemia the glutamate concentration in glial cells rises (Storm-Mathisen et al., 1992). Because activation of the anion conductance in glial uptake carriers can be potentiated by intracellular glutamate (Fig. 5B), it is possible that the uptake carrier might contribute to the glial cell chloride conductance, which, by allowing $\mathrm{Cl}^{-}$influx, could facilitate glial cell swelling in ischemia (Walz et al., 1993).

\section{REFERENCES}

Amato A, Barbour B, Szatkowski M, Attwell D (1994) Countertransport of potassium by the glutamate uptake carrier in glial cells isolated from the tiger salamander retina. J Physiol (Lond) 479:371-380.

Attwell D, Barbour B, Szatkowski M (1993) Nonvesicular release of neurotransmitter. Neuron 11:401-407.

Baetge EE, Bulloch K, Stallcup WB (1979) A comparison of glutamate uptake in cloned cell lines from the central nervous system. Brain Res 167:210-214.

Barbour B, Brew H, Attwell D (1988) Electrogenic glutamate uptake in glial cells is activated by intracellular potassium. Nature 335:433-435.

Barbour B, Brew H, Attwell D (1991) Electrogenic uptake of glutamate and aspartate into glial cells isolated from the salamander retina. J Physiol (Lond) 436:169-193.

Billups B, Attwell D (1996) Modulation of nonvesicular glutamate release by $\mathrm{pH}$. Nature 379:171-174.

Bouvier M, Szatkowski M, Amato A, Attwell D (1992) The glial cell glutamate uptake carrier countertransports $\mathrm{pH}$-changing anions. Nature 360:471-473.

Brew H, Attwell D (1987) Electrogenic glutamate uptake is a major current carrier in the membrane of axolotl retinal glial cells. Nature 327:707-709.

Eliasof S, Jahr S (1996) Retinal glial cell glutamate transporter is coupled to an anionic conductance. Proc Natl Acad Sci USA 93:4153-4158.

Eliasof S, Werblin F (1993) Characterization of the glutamate transporter in retinal cones of the tiger salamander. J Neurosci 13:402-411.

Erecinska M, Wantorsky D, Wilson DF (1983) Aspartate transport in synaptosomes from rat brain. J Biol Chem 258:9069-9077.

Fairman WA, Vandenberg RJ, Arriza JL, Kavanaugh MP, Amara SG (1995) An excitatory amino-acid transporter with properties of a ligand-gated chloride channel. Nature 375:599-603.

Fenwick EM, Marty A, Neher E (1982) A patch-clamp study of bovine chromaffin cells and of their sensitivity to acetylcholine. J Physiol (Lond) 331:577-597.

Grant GB, Dowling JE (1995) A glutamate-activated chloride current in cone-driven ON bipolar cells of the white perch retina. J Neurosci 15:3852-3862.

Honore T, Drejer J (1988) Chaotropic ions affect the conformation of quisqualate receptors in rat cortical membranes. J Neurochem 51:457-461.

Kanner BI, Bendahan A (1982) Binding order of substrates to the sodium and potassium ion-coupled L-glutamic acid transporter from rat brain. Biochemistry 21:6327-6330.

Kanner BI, Sharon I (1978) Active transport of L-glutamate by membrane vesicles isolated from rat brain. Biochemistry 17:3949-3953.

Nelson PJ, Dean GE, Aronson PS, Rudnick G (1983) Hydrogen ion cotransport by the renal brush border glutamate transporter. Biochemistry 22:5459-5463.

Picaud SA, Larsson HP, Grant GB, Lecar H, Werblin FS (1995) Glutamate-gated chloride channel with glutamate-transporter-like 
properties in cone photoreceptors of the tiger salamander. J Neurophysiol 74:1760-1771.

Rothstein JD, Dykes-Hoberg M, Pardo CA, Bristol LA, Jin L, Kuncl RW, Kanai Y, Hediger MA, Wang Y, Schielke J, Welty DF (1996) Functional defects of glial but not neuronal glutamate transporters are responsible for glutamate toxicity. Neuron 16:675-686.

Sarantis M, Everett K, Attwell D (1988) A presynaptic action of glutamate at the cone output synapse. Nature 332:451-453.

Stallcup WB, Bulloch K, Baetge EE (1979) Coupled transport of glutamate and sodium in a cerebellar nerve cell line. J Neurochem 32:57-65.

Storm-Mathisen J, Danbolt NC, Rothe F, Torp R, Zhang N, Aas J-E, Kanner BI Langmoen I, Ottersen OP (1992) Ultrastructural immunocytochemical observations on the localization, metabolism, and transport of glutamate in normal and ischemic brain tissue. Prog Brain Res 94:225-241.

Szatkowski M, Barbour B, Attwell D (1990) Nonvesicular release of glutamate from glial cells by reversed electrogenic glutamate uptake. Nature 348:443-446.

Szatkowski M, Barbour B, Attwell D (1991) The potassium dependence of excitatory amino acid transport: resolution of a paradox. Brain Res 555:343-345.

Vandenberg RJ, Arriza JL, Amara SG, Kavanaugh MP (1995) Constitutive ion fluxes and substrate binding domains of human glutamate transporters. J Biol Chem 270:17668-17671.

Wadiche JI, Amara SG, Kavanaugh MP (1995) Ion fluxes associated with excitatory amino acid transport. Neuron 15:721-728.

Walz W, Klimaszewski A, Paterson IA (1993) Glial swelling in ischemia: a hypothesis. Dev Neurosci 15:216-225.

Wright EM, Diamond JM (1977) Anion selectivity in biological systems. Physiol Rev 57:109-156. 